\title{
Study on Bovine Mastitis under Different Management in Pastoral and Agro-Pastoral Areas of Borana Zone, Southern Ethiopia
}

\section{Kumbe A*, Bekele B, Hussien B, Onate A and Teshome D}

Institute of Oromia Agricultural Research, Yabello Pastoral and Dry land Agriculture Research Center, Ethiopia

*Corresponding author: Adem Kumbe, Institute of Oromia Agricultural Research, Yabello Pastoral and Dry land Agriculture Research Center, P.O. Box 85, Yabello, Ethiopia, Email: ademkumbe7@gmail.com

\section{Research Article \\ Volume 5 Issue 1}

Received Date: December 29, 2019

Published Date: March 04, 2020

DOI: 10.23880 /oajvsr-16000192

\section{Abstract}

A cross-sectional study was conducted to determine the prevalence of bovine mastitis, associated potential risk factors and major etiological agents of clinical and sub clinical mastitis under different management condition of pastoral, agro-pastoral, ranch and farm by using California mastitis test and bacteriology. A total of 384 lactating Borana cows in Did-tuyura ranch, Yabello Pastoral and dryland agriculture research center (YPDARC) dairy farm and three districts namely Gomole, Moyale and Yabello of Borana zone were included in the study. The study revealed that overall prevalence of mastitis were $47.4 \%$ (182/384); out of which $12 \%$ (46/384) clinical and 35.4\% (136/384) sub-clinical mastitis whereas prevalence at quarter level was $21.48 \%$ (330/1536) of which 3\% (46/1536) and 18.48\% (284/1536) were clinical and sub-clinical form respectively. From the total examined quarter, 3.5\% (53) of quarters had blind quarter. Prevalence in pastoral and agro-pastoral herding system (extensive management system) at cow level and quarter level were 18.9\% and $10.9 \%$ respectively while prevalence in Did-tuyura ranch and YPDARC dairy farm herding system (semi-intensive) were 20\% and 7\% at cow level and quarter level respectively. The prevalence of mastitis significantly $(\mathrm{P}<0.05)$ differed with parity, stage of lactation and body condition of lactating animals. From 330 California Mastitis Test (CMT) and clinically positive milk samples there was growth of bacteria on culture media observed only in 155 (46.97\%). Out of this Staphylococcus aureus accounted for 59 (38.06\%) isolates followed by Streptococcus species 33 (21.29\%) and Coagulase negative Staphylococcus 30 (19.35\%). Due to lack of proper managements of different risk factors major pathogenic microorganisms are isolated. Proper preventive and control strategy, awareness creation on key factors of mastitis, Regular screening and culling of chronically infected cows should be practiced.

Keywords: Boran Cows; Bacterial Isolates; Borana; Mastitis; Prevalence

\section{Introduction}

Ethiopia has the largest cattle population in Africa, which is estimated at 53.99 million animals of which 7.2 million are primarily held for milk production [1]. Despite these large numbers, milk production often does not satisfy the country's requirements due to a multitude of factors amongst which the occurrence of mastitis has great prominence. In terms of livestock population, Ethiopia has the largest population of any African country. Furthermore, cows represent the largest population of cattle production 


\section{Open Access Journal of Veterinary Science \& Research}

of the country. However; milk production often does not satisfy the countries requirement. According to the reports of [2] the total annual national milk production from cattle, camel and goat in Ethiopia was reach 3,031,860 metric tons raw milk, Out of the total national milk production cows produce 2,411,291 metric tons. However, this amount is by far below the national demand for milk and milk products in the country, given the considerable potential for small holder income and employment generation from high value dairy products. Development of the dairy sector in Ethiopia can contribute significantly to poverty alleviation and nutrition in the country [3].

Mostly in Ethiopia, Cows are kept to provide milk primarily for household consumption and reproduce for production of draught oxen and replacement heifers. Surplus milk is sold, usually by women, who use the regular cash income to buy household necessities or to save for festival occasions [4]. Generally, Milk and milk products play a very important role in feeding the rural and urban population of Ethiopia and have a high nutrition value and is daily produced, sold for cash. It is a cash crop in the milk-shed areas that enables families to buy other foodstuffs, contributing significantly to the household food security [1].

Milk is one of the most important livestock products among the pastoralists in the Borana pastoral communities. It is the main diet for pastoralists [5]. Nevertheless the quality and quantity of milk in the country deteriorates due to various causes. Mastitis imposes a serious problem cause reduction in milk production and remains one of the most economically important diseases for the dairy industry worldwide irrespective of the species of animals [6]. Mastitis is the inflammation of the mammary gland that has over 130 different isolated causative agents from mastitis milk samples but Staphylococcus aureus, Streptococci, and members of the Enterobacteriaceae are among the most common etiological agents in cows and in other animal species [7]. Mastitis can cause devastating effects to farmers because of the serious economic losses and the danger that the bacterial contamination of milk from affected cows may render it unsuitable for human consumption. It is often classified as subclinical or clinical depending on the severity of the disease or contagious and environmental based on the causative agents [8]. The occurrence of mastitis depends up on the complex interaction among three factors; host, agent and environment. Hence, any mastitis control program must be designed towards correcting mastitis problem associated with three epidemiological components [9].

The study area is one of the most known pastoralist area in the country in which milk is primary purpose cattle production and potential area, but less considered. Therefore, the present study is designed to determine the prevalence of bovine mastitis under different management in Borana zone, assess mastitis occurrence with some associated potential risk factors in study area and to isolate and identify major etiological agents of clinical and sub clinical mastitis in study area.

\section{Materials and Methods}

\section{Study Area}

The study was conducted from September 2017 to May 2018 in YPDARC dairy farm, Did-tuyura ranch and three districts of Borana zone of Oromia Regional State, southern Ethiopia, which are located South of Addis Ababa, bordering northern Kenya and the Somali Regional State of Ethiopia. Delivery of rainfall is bimodal but erratic and unreliable in distribution. Rainfall distribution is season based here in Borana pastoral and agro-pastoral settings as long rainy season "Gannaa" from March to May, a cold dry season "Adoolessa" from June to August, short rainy season "Hagayyaa" from September to November, and a long dry season "Bonaa" from December to February [10].

\section{Sampling Method and Sample Size Determination}

Districts were purposively selected and multi-stage random sampling procedure was followed to take PAs, ollas, households and cattle. The minimum sample size required for this study was determined by using the following sample determination formula according to Thrusfield.

$$
\mathrm{n}=\frac{1.962(\operatorname{Pexp}(1-\mathrm{Pexp})}{\mathrm{d} 2}
$$

Where: $\mathrm{n}=$ required sample size; $1.96=$ the value of $\mathrm{z}$ at 95\%of confidences level. Pexp= prevalence of bovine mastitis $=$ desired absolute precision level at 95\% confidence. According to the formula Thrusfield a minimum of 384 cow's be sampled.

\section{Study Population}

The study population consisted at cattle find Did-tuyura ranch, YPDARC dairy farm and owned by Borana pastoralist those find in three districts namely Gomole, Moyale and Yabello.

\section{Study Design}

A cross-sectional study was conducted to determine the prevalence, etiology and associated risk factor of bovine mastitis in study area, by using clinical observation and milk sample collected from randomly selected lactating cows by using CMT and microbiological examination of samples 


\section{Open Access Journal of Veterinary Science \& Research}

from all CMT positive quarters. Data related to risk factors associated with mastitis were recorded by questionnaires by interviewing the househlold. The potential risk factors considered in this study for the occurrence of bovine mastitis were milking sequence, quarter location and type of management, lactation stage, age, body conditions, tick infestation and parity number. Data on these related to clinical mastitis, udder and milk abnormalities (blindness, swelling, blood tinged milk and other abnormalities), and direct observation were also recorded.

\section{Data Collection}

\section{Investigation Procedures}

Diagnosis of clinical mastitis: Clinical examination was employed for the diagnosis of clinical mastitis. Clinical mastitis was characterized by grossly detectable changes in the milk and mammary gland and also signs of systemic disturbance in the cow. It was also recognized by some pathology in udder, which is manifested by swelling, pain, redness and heat in acute cases. Whereas hardening of udder, blockage of teats, atrophy or fibrosis and abscess formation were characteristic of chronic mastitis. Acute mastitis was also recognized by deviation in milk color, consistency, presence of flakes and clots. A cow found with one or more of its quarters to be blind was considered as positive for clinical mastitis whether or not it has another quarter with active infection [11].

Diagnosis of subclinical mastitis: Subclinical mastitis was diagnosed based on CMT results and or the nature of coagulation and viscosity of the mixture (milk and CMT reagent), which show the presence and severity of the infection, respectively. The CMT was used also as screening test for selection of samples for culture from the cows under study. The test was conducted just before milking, after stimulating the cow and having discarded the fore milk. From each quarter of the udder, a squirt of milk sample was placed in each of four compartments of CMT paddle and an equal amount of 3\% CMT reagent was added to it and mixed thoroughly. Reaction was scored as 0 , for negative; 1,2 , and 3 for positive [8].

\section{Bacteriological Examination of Milk Samples}

Udder and teat preparation: The udder, especially the teats were cleaned and dried with clean towel before milk sample collection. The teats were washed with tap water and dried. Then, the teats were swabbed with cotton, soaked in $70 \%$ ethyl alcohol.

Milk sample collection: Milk samples were collected aseptically after the teat ends were cleaned with cotton moistened in $70 \%$ ethyl alcohol according to the procedures recommended by national mastitis council. To reduce Contamination of the teat ends during sample collection, the near teats were sampled first followed by the far once. About $10-12 \mathrm{ml}$ of milk was collected in to a sterile sample vial after discarding the first three streams of milk. Then samples were placed in an ice cooler box and transported to Yabello regional veterinary laboratory for immediate microbiological examination.

Bacterial Isolation: Milk samples from CMT positive quarters were subjected to bacteriological isolation according to the procedure employed by Quinn, et al. [7]. In refrigerated milk samples, bacteria may be concentrated in the cream layer and held with in clumps of fat globules. Hence, dispersion of fat and bacteria was accomplished by warming the samples at $25^{\circ} \mathrm{c}$ for 15 minutes and shake before plating on standard bacteriological media. A loopful of milk sample collected from each CMT positive quarter was inoculated separately on to blood agar base enriched with $7 \%$ defibrinated sheep blood. The inoculated plates were then incubated aerobically at 370c for 24 up to 48 hours. For primary identification of bacteria to generic level, colony morphology and size, hemolytic characteristics, Gram reaction including shape and arrangements of bacteria, catalase test were employed. Streptococci were identified based on catalase test and morphology and arrangements in Gram staining. Staphylococci were identified based on growth characteristics on blood agar, Gram staining, coagulase test and catalase test. Interpretation was made according to National Mastitis council. The culture was considered negative if no growth occurs after 24, 48 and 72 hours of incubation. Isolation of two or more colonies from a quarter samples was considered contaminated and the result was disregarded. However, S.aureus and str. agalactiae from contaminated sample was considered a causal.

\section{Data Analysis}

Data collected from field and laboratory result were entered and stored in microsoft excel spread sheet, screened for proper coding and errors and transported to statistical software for analysis. For the statistical analysis SPSS version 20 and chi-square (x2) test were used. Disease associated risk factors with a P-value less than 0.05 were considered significant.

\section{Results}

\section{Prevalence}

The prevalence of mastitis at cow and quarter level was $47.4 \%(182 / 384)$ and $21.48 \%$ (330/1536), respectively. Tables $1 \& 2$ summarizes the prevalence in pastoral and agro-pastoral herding system (extensive management system) at cow level and quarter level were $18.9 \%$ and 


\section{Open Access Journal of Veterinary Science \& Research}

$10.9 \%$ respectively while prevalence in Did-tuyura ranch and YPDARC dairy farm herding system (semi-intensive) were $20 \%$ and $7 \%$ at cow level and quarter level respectively. From the total of 384 lactating cows examined $46(12 \%)$ had clinical and $136(35.4 \%)$ had subclinical mastitis (Table
3). Out of the total 1536 quarters examined prevalence of mastitis was $21.48 \%$, out of $3 \%$ were clinical and $18.48 \%$ were subclinical whereas $53(3.5 \%)$ quarters had blind teats (Table 4).

\begin{tabular}{|c|c|c|c|c|c|}
\hline \multirow{4}{*}{ Location } & \multicolumn{2}{|c|}{ Clinical mastitis } & \multicolumn{2}{|c|}{ Sub-clinical mastitis } \\
\cline { 3 - 6 } & & Cow level & Quarter level & Cow level & Quarter level \\
\cline { 3 - 6 } & & Positive (\%) & Positive (\%) & CMT positive (\%) & Positive (\%) \\
\hline \multirow{3}{*}{ Pastoral } & Dambi & $7(1.82)$ & $7(0.5)$ & $15(3.9)$ & $22(1.43)$ \\
\cline { 2 - 6 } & Bokola & $4(1.04)$ & $4(0.3)$ & $4(1.04)$ & $11(0.72)$ \\
\cline { 2 - 6 } & Dadim & $4(1.04)$ & $4(0.3)$ & $13(3.4)$ & $15(0.97)$ \\
\hline \multirow{3}{*}{ Agro-pastoral } & Dida yabello & $5(1.3)$ & $5(0.32)$ & $15(3.9)$ & $37(0.24)$ \\
\cline { 2 - 6 } & Cholkasa & $5(1.3)$ & $5(0.32)$ & $13(3.4)$ & $30(1.95)$ \\
\cline { 2 - 6 } & Buya & $4(1.04)$ & $4(0.3)$ & $16(4.2)$ & $23(1.5)$ \\
\hline Farm & YPDARC dairy farm & $2(0.5)$ & $2(0.1)$ & $6(1.6)$ & $7(0.5)$ \\
\hline Ranch & Did-Tuyura ranch & $15(3.9)$ & $15(1)$ & $54(14.1)$ & $84(5.5)$ \\
\hline
\end{tabular}

Table 1: Overall prevalence of mastitis in all selected study area $N=384, n=1536$.

\begin{tabular}{|c|c|c|c|c|}
\hline \multirow{2}{*}{$\begin{array}{c}\text { Different management } \\
\text { systems }\end{array}$} & \multicolumn{2}{|c|}{ Clinical mastitis } & \multicolumn{2}{c|}{ Sub-clinical mastitis } \\
\cline { 2 - 5 } & Cow level & Quarter level & Cow level & Quarter level \\
\cline { 2 - 5 } & Positive (\%) & Positive (\%) & CMT positive (\%) & Positive (\%) \\
\hline Pastoral & 3.9 & 0.97 & 8.33 & 3.13 \\
\hline Agro-pastoral & 6.25 & 2.34 & 11.45 & 5.85 \\
\hline YPDARC dairy farm & 0.5 & 0.1 & 1.6 & 0.5 \\
\hline Did-Tuyura ranch & 3.9 & 1 & 14.1 & 5.5 \\
\hline
\end{tabular}

Table 2: prevalence of mastitis in different management area $\mathrm{N}=384, \mathrm{n}=1536$.

\begin{tabular}{|c|c|c|c|c|}
\hline \multirow{2}{*}{ Type of mastitis } & \multicolumn{2}{|c|}{ Cow level (N=384) } & \multicolumn{2}{c|}{ Quarter level (n= 1536) } \\
\cline { 2 - 5 } & Positive & Prevalence & Positive & Prevalence \\
\hline Clinical & 46 & 12 & 46 & 3 \\
\hline Sub-clinical & 136 & 35.4 & 284 & 18.48 \\
\hline Total & 182 & 47.4 & 330 & 21.48 \\
\hline
\end{tabular}

Table 3: Prevalence of clinical and subclinical mastitis at cow and quarter level.

\begin{tabular}{|c|c|c|}
\hline Udder quarter & Positive (\%) & Blind teat (\%) \\
\hline Left front quarter & $74(4.8)$ & $13(0.85)$ \\
\hline Left hind quarter & $114(7.4)$ & $13(0.85)$ \\
\hline Right front quarter & $65(4.2)$ & $9(1.2)$ \\
\hline Right hind quarter & $77(5)$ & $53(3.5)$ \\
\hline Total & $330(21.48)$ & $5.6)$ \\
\hline
\end{tabular}

Table 4: Frequency and percentage of mastitis cows by the number of affected quarters (No of cow= 384; no of quarter=1536. 


\section{Open Access Journal of Veterinary Science \& Research}

\section{Potential Risk Factors}

The study result showed parity number, lactation stage and body condition had significant effect $(\mathrm{P}<0.05)$ on the prevalence of mastitis (Table 5). In this result prevalence of mastitis was higher in both animals with moderate and higher number of parity had 35.4 and $42.06 \%$ of mastitis respectively. However cows with few calves (25.3\%) had lower result of mastitis. Cows in their early stage of lactation suffered most from mastitis compared to cows in their mid and late stage of lactation $(\mathrm{P}<0.05)$. Concerning body condition, the prevalence was high in both poor body condition $(42.86 \%)$ and moderate body condition (46.1\%) when compared to good body condition (8.41\%). According to the result related to prevalence mastitis in association with tick infestation and age of animals were insignificant $(\mathrm{P}>0.05)$.

\begin{tabular}{|c|c|c|c|c|c|}
\hline Factors & Groups & No. of cows & Prevalence (\%) & $X^{2}$ & $P$ value \\
\hline \multirow{3}{*}{ Parity } & $1-3$ calves (few) & 83 & 25.3 & & 0.046 \\
\hline & 4-5 calves (moderate) & 126 & 42.06 & 6.147 & \\
\hline & 6 (many) & 175 & 35.4 & & \\
\hline \multirow{3}{*}{ Lactation stage } & 1 (1-3 month) & 238 & 52.1 & 78.47 & 0 \\
\hline & 2 (4-6 month) & 30 & 20 & & \\
\hline & 3 (>7month) & 116 & 30.2 & & \\
\hline \multirow{2}{*}{ Tick infestations } & Absent & 30 & 26.67 & 1.089 & 0.297 \\
\hline & Present & 354 & $128(36.2)$ & & \\
\hline \multirow{3}{*}{ Body condition } & Poor & 21 & 42.86 & 47.383 & 0 \\
\hline & Medium & 256 & 46.1 & & \\
\hline & Good & 107 & 8.41 & & \\
\hline Age & 3-5year (young adult) & 71 & 26.76 & 2.853 & 0.09 \\
\hline
\end{tabular}

Table 5: Association of potential risk factors with prevalence of mastitis at cow level.

\section{Bacterial Isolation}

Milk Samples collected from CMT and clinically positive quarters (330) cultured for microbiological examination and growth of bacteria were observed only in 155 (46.97\%) milk samples. Out of these isolates, $35(22.5 \%)$ and $120(77.42 \%)$ were from clinical and subclinical mastitis respectively. Staphylococcus aureus accounted for 59 (38.06\%) isolates followed by Streptococcus species $33(21.29 \%)$ and Coagulase negative Staphylococcus 30 (19.35\%) (Table 6).

\begin{tabular}{|c|c|c|c|}
\hline \multirow{2}{*}{ Bacterial isolates } & \multicolumn{2}{|c|}{ Numbers of bacterial isolates } & \multirow{2}{*}{ Total (\%) } \\
\cline { 2 - 4 } Coagulase negative Staphylococcus & Clinical mastitis (\%) & Subclinical mastitis (\%) & \multirow{2}{*}{$30(19.35)$} \\
\hline Staphylococcus aureus & $16(10.32)$ & $14(9.03)$ & $59(38.06)$ \\
\hline Streptococcus species & $16(10.32)$ & $43(27.74)$ & $33(21.29)$ \\
\hline Micrococcus species & $2(1.29)$ & $31(20)$ & $11(7.09)$ \\
\hline Other Gram positive rod and cocci & $1(0.65)$ & $10(6.45)$ & $14(9.03)$ \\
\hline Gram negative rods & - & $14(9.03)$ & $8(5.16)$ \\
\hline Total & - & $8(5.16)$ & $155(100)$ \\
\hline
\end{tabular}

Table 6: Relative occurrences of bacteria isolated from clinical and subclinical mastitis.

\section{Discussion}

The present result in study area revealed an overall prevalence of $47.4 \%$ at cow level and $21.48 \%$ at quarter level. This result relatively agrees with prevalence of $52.78 \%$ around sebeta and 44.78 in sidamo zone reported by sori, et al. [12] and Yibrah Tekle and Tsega Berihe respectively. 


\section{Open Access Journal of Veterinary Science \& Research}

Prevalence of this finding was found lower than finding of wubishet, et al. [13] in selected districts of Borana Zone, bedane, et al. [14] in yabello district and Tesfaheywet Zeryehun and Gerema Abera [15] of Eastern Harrarghe Zone reported the prevalence of 70.8, 59.1 and $64.3 \%$ respectively. However, the current finding was higher than prevalence of $7.2 \%, 8.7 \%, 11.1 \%$ and $24.5 \%$ reported by Nesru, et al. [16] in central Ethiopia, in and around Addis Ababa, [17] around Mekelle and Kefele and Biruk [18] from Wolayta Soddo respectively.

The present study also showed prevalence of $12 \%$ for clinical mastitis was closer to $12.5 \%$ and $12.4 \%$, reports of Tesfaheywet and Gerema [15] in Eastern Harrarghe Zone, and wubishet, et al. [14] in selected districts of Borana zone respectively. However, it was higher than that of Bishi [16] who reported the prevalence of 5.3\%, in Addis Ababa Ethiopia and Tolosa, et al. who recorded the prevalence of 9.5\% at Wolayta Soddo. The prevalence of, 25.1\% 16.11\% and $30.17 \%$ were also reported by Workineh, et. al. Hundra, et al. and Hasen, et al. $[19,20]$ respectively in and around Addis Ababa, and Bench maji south west Ethiopia, that was higher than the current finding. The difference in results could be due to difference in management system between husbandary practices.

Occurrence of subclinical mastitis was found high when compared to clinical mastitis. The prevalence of subclinical mastitis based on CMT test in the present study was (35.4\%), which is in close agreement with (38\%) the reports done by Bedane, et al. [14] in the same area. It was lower than report of Tesfaheywet and Gerema [15] that was 51.8\% and Jirata and Indalem [21] was reported 61.19\%. However, the present report is higher than $26.9 \%$ and $19.6 \%$ reports of Mulugeta and Wassie, and Kefele and Biruk [18] respectively.

The quarter level prevalence of mastitis in the present study was $21.48 \%$, out of $3 \%$ were clinical and $18.48 \%$ were subclinical. This result is far lower than findings of $62.3 \%$ at Addis Ababa [22] and $47.52 \%$ at Addis Ababa and Sebeta Town [23]. Similarly, Mekibib, et al. [24] reported an overall prevalence of $44.9 \%$ around Holeta Town, where $10 \%$ and $34.8 \%$ represent prevalence of clinical and subclinical mastitis.

However, prevalence recorded in the current study is higher than finding of Haftu, et al. $15.4 \%$; from which, 11.9 subclinical form and $2.4 \%$ were of clinical form and report of Bitew, et al. [25] (12.3\%) infection of sub clinical mastitis. The finding of $3.5 \%$ blind teat in this study is in agreement with the previous reports $3.32 \%$ of Lakew, et al. [26] and higher when compared with the report of Haftu, et al. and Bitew et al. of which $1.1 \%$ and $1.9 \%$ respectively. However this result was lower than report (6.6\%) of Tesfaheywet and

\author{
Gerema Abera [15].
}

The difference may be due to greater experience in drying off, the potential effect of level of milking hygiene, herd size and cleanness, and the application of sanitary measures. With regard to prevalence of mastitis in each quarter of the udder, the left hindquarters were affected with the highest infection rate $7.4 \%$. The right hindquarters were the second with an infection rate of 5\%. Zeryehun, et al. [22] attributed the highest infection rates in these quarters to the high production capacity of the rear quarters and the high chance of getting fecal and environmental contamination.

Association of mastitis occurrence with parity, body condition and lactation stage were found statistically significant $(\mathrm{P}<0.05)$. According to the result higher infection in cows in early lactation stage followed by medium and late lactation stages that concurs with previous reports [27]. The early lactation stage infection might be due to the carryover of infection from dry period. In cows most new infections occur during the early part of the dry period and in the first two months of lactation (Radostits et. al., 2007). The increase in prevalence of mastitis with parity reported in the study is comparable with the previous reports [27-29]. This might be due to the increased opportunity of infection with time and the prolonged duration of infection, especially in a herd without mastitis control program and also an increase for teat injuries [30].

In the present study the causes of mastitis were Staphylococcus aureus (38.06\%) followed by streptococcus species (21.29\%) and coagulase negative Staphylococcus $(19.35 \%)$. The high prevalence of S. aureus in this study is in accordance with other workers [20]. High prevalence of S. aureus points to poor milking time hygiene as this pathogen is mainly spread during milking via milkers' hands and towels [6]. The finding of Streptococcus species was in agreement with Bedane, et al. [14], Fentaye, et al. Kefele and Biruk [18] which were 21.5, 23.5 and $25.49 \%$ respectively [31-35]. The relative isolation of this organism in this study may due to poor milking time hygiene, absence of post milking teat dipping, lack of proper treatment for clinically infected animals and absence culling of non-responding of dry period therapy cows.

\section{Conclusion and Recommendations}

Generally, mastitis is one of the complex diseases of dairy cows which involve an interaction between management practice and infectious agent occurring throughout the world. The present study indicated considerable prevalence of the disease with the isolation of major pathogenic microorganisms from both clinical and subclinical mastitis. The disease has also been reported in different parts of 


\section{Open Access Journal of Veterinary Science \& Research}

Ethiopia with varying prevalence. Inadequate hygienic condition of dairy cow, poor milking method, poor animal health service and lack of proper attention to the health of the mammary gland were important for the prevalence in the study area. The impact of diseases on lactating cows is occurred due to increment of risk factor for infection of mammary glands.

Therefore, based the above conclusions the following point forwarded:

- Preventive and control strategy of mastitis should have established that focusing up on awareness on key factors of mastitis such as good herd management, washing hands before and after milking, preparation of clean towel for each lactating cow and milking of infected cow lastly.

- Standard milking procedure, such as pre and post milking udder washing should be applied to reduce the risk of transmission.

- Regular screening of subclinical mastitis for early detection and treatment, and culling of chronically infected cows should be practiced in ranch and farm.

- To reduce the impact of the disease on milking cows, appropriate control measures targeting to reduce risk of infection should be in place, and awareness needs to be created to pastoralists/agro-pastoralists on the impact of the disease.

\section{Conflict of Interest Statement}

I declare that this paper is original and my own work results.

\section{References}

1. CSA (Central Statistical Authority) (2009) Ethiopian Statistical Abstract. CSA, Addis Ababa, Ethiopia.

2. MOFED and MOA (Ministry of finance and economic development and ministry of agriculture) (2011) A review to improve estimation of livestock contribution to the national GDP. MOFED, Addis Ababa, Ethiopia.

3. Mohamed AMA, Simeon E, Yemesrach A (2004) Dairy development in Ethiopia. Mosby Publishing, London, pp: 327-344.

4. Zewdu W (2004) Indigenous cattle genetic resource, their husbandry practices and breeding objectives in northwestern Ethiopia. MSc thesis. Alemaya University, Ethiopia.

5. Coppock DL (1993) The Borana Plateau of Southern Ethiopia: Synthesis of Pastoral Research, Development, and Changes, 1980-1991. ILCA System Study, pp: 43-288.

6. Bradley AJ (2002) Bovine Mastitis: an Evolving disease.
Vet J 164(2): 1-13.

7. Quinn PJ, Carter ME, Markey B, Carter GR (1999) Clinical Veterinary Microbiology.

8. Quinn PJ, Markey BK, Carter ME, Donelly WJ, Leonard FC (2002) Veterinary Microbiology and Microbial Disease. $2^{\text {nd }}$ [Edn.], Blackwell Science Ltd, a Blackwell publishing Company, pp: 465-475.

9. Radostits OM (2001) Herd Health: Food Animal Medicine. $3^{\text {rd }}$ (Edn.), W.B. Sounders Company, USA, pp: 673-749.

10. Kamara A, Swallow B (2005) Poverty rights and Land use change: Implications for sustainable resource management in Borana, Southern Ethiopia. J Sustain Agric 25(2): 45-65.

11. Kivaria FM, Noordhuizen JPTM, Msami HM (2007) Risk factors associated with the incidence rate of clinical mastitis in smallholder dairy cows in the Dares Salaam region of Tanzania. The Veterinary Journal 173(3): 623629.

12. Sori H, Zerihun A, Abdicho S (2005) Dairy cattle mastitis in and around Sebeta. Intern J Appl Res Vet Med 3: 338341.

13. Wubishet Z, Ararsa D, Alemayehu L (2013) Bovine Mastitis In Selected Districts Of Borena Zone, Southern Ethiopia. Yabelo Bull Anim Hlth Prod Afr 61(3): 173-179.

14. Adane B, Guyo K, Tekle Y, Taddele H, Bogale A, et al. (2012) Study on Prevalence and Risk Factors of Bovine Mastitis in Borana Pastoral and Agro-Pastoral Settings of Yabello District, Borana Zone, Southern Ethiopia. American Eurasian J Agric \& Environ Sci 12(10): 12741281.

15. Tesfaheywet Z, Gerema A (2017) Prevalence and Bacterial Isolates of Mastitis in Dairy Farms in Selected Districts of Eastern Harrarghe Zone, Eastern Ethiopia. Journal of Veterinary Medicine 2017: 7.

16. Bishi A, (1998) Cross-sectional and longitudinal prospective study of bovine clinical and subclinical mastitis in per urban and urban dairy production systems in the Addis Ababa region, Ethiopia. Faculty of Veterinary Medicine, Addis Ababa University School of Graduate Studies and Freie Universitat, Berlin. MSc. Thesis.

17. Wudu TA (1999) Study of bovine mastitis in and around Mekelle. Thesis, Debre Zeit Faculty of veterinary medicine Addis Ababa University, Ethiopia.

18. Kefele Y, Biruk A (2018) Prevalence of Bovine Mastitis in 


\section{Open Access Journal of Veterinary Science \& Research}

lactating Cows and Associated risk factors in and around Wolayta Soddo, Southern Ethiopia. Int J Adv Res Biol Sci 5(12): 60-69.

19. Workineh S, Bayleyegn M, Mekonnen H, Potgieter LND (2002) Prevalence and aetiology of Mastitis in cows from two major Ethiopian dairies. Tropical Animal Health and Production 34(1): 19-25.

20. Hundera S, Ademe Z, Sintayeu A (2005) Dairy cattle mastitis in and around Sebate, Ethiopia. Int J apples vet med 3(4): 332-338.

21. Jirata S, Indalem T (2016) Prevalence of Bovine Mastitis and Assessment of Risk Factors in and around Wolayta Sodo, Ethiopia. International Journal of Homeopathy \& Natural Medicines 2(1): 1-7.

22. Zeryehun T, Aya T, Bayecha R (2013) Study on prevalence, bacterial pathogens and associated risk factors of bovine mastitis in small holder dairy farms in and around Addis Ababa, Ethiopia. Journal of Animal and Plant Sciences 23(1): 50-55.

23. Belay G (2011) Prevalence of bovine subclinical mastitis in dairy farms of Addis Ababa and Sebeta Town (DVM thesis), Haramaya University College of Veterinary Medicine, Haramaya, Ethiopia.

24. Mekibib B, Furgasa M, Abunna F, Megersa B, Regassa A (2010) Bovine mastitis: prevalence, risk factors and major pathogens in dairy farms of holeta town, central Ethiopia. Veterinary World 3(9): 397-403.

25. Bitew M, Tafere A, Tolosa T (2010) Study on Bovine Mastitis in Dairy Farms of Bahir Dar and its Environs. J Anim Vet Adv 9(23): 2912-2917.

26. Lakew M, Tolosa T, Tigre W (2009) Prevalence and major bacterial causes of bovine mastitis in Asella, South Eastern Ethiopia. Tropical Animal Health and Production
41(7): 1525-1530.

27. Tamirat TA (2007) Comparison of clinical trials of bovine mastitis with the use of honey, MSc thesis, Addis Ababa University, Ethiopia, pp: 14-30.

28. Moges N, Asfaw Y, Belihu K (2011) Across sectional study on the prevalence of subclinical mastitis and associated risk factors in and around Gondar, Northern Ethiopia. Int J Ani Vet Adv 3(6): 455-459.

29. Biniam T, Rediet T, Yonus A (2015) Prevalence and potential risk factors of bovine mastitis in selected dairy farms of dire Dawa town, Eastern Ethiopia. Appl J hygiene 4(1): 6-11.

30. Radostitis OM, Gay CC, Hinchcliff KW, Constable PD (2007) Mastitis. In: Veterinary medicine: a text book of disease of cattle, sheep, pigs, goats, and horses, $10^{\text {th }}$ (Edn.), Ballier, Tindall, London, pp: 674-762.

31. Central Statistical Agency of Ethiopia (CSA) (2011) Report on livestock and livestock characteristics (private peasant holdings). Agricultural sample survey.

32. Dego OK, Tareke F (2003) Bovine mastitis in selected areas of southern Ethiopia. Trop Anim Health Prod 35(3): 197-205.

33. Ahmed MAM, Ehui S, Yemesrach A (2004) Dairy development in Ethiopia. International Food Policy Research Institute, EPTD Discussion Paper No. 123. Washington, DC, USA, pp: 58.

34. Korhonen H, Kaartinen L (1995) Changes in the composition of milk induced by mastits. In: Sandholm M, (Eds.), The bovine udder and mastitis, University of Helsinki, Finland, pp: 76-82.

35. Yohannes K, Basore B (2018) Prevalence of Bovine Mastitis in lactating Cows and Associated risk factors in and around Wolayta Soddo, Southern Ethiopia, pp: 12. 